\title{
Investigation of The Sufficiency of Antalya Parks
}

\author{
Orhun Soydan ${ }^{1, a, *}$, Nefise Çetin ${ }^{2, b}$ \\ ${ }^{1}$ Landscape Architecture Department, Faculty of Architecture, Niğde Ömer Halisdemir University, 51240 Niğde, Turkey \\ ${ }^{2}$ Landscape Architecture Department, Faculty of Architecture, Akdeniz University, 07070 Antalya, Turkey \\ ${ }^{*}$ Corresponding author

A R T I C L E I N F O A B S T R A C T

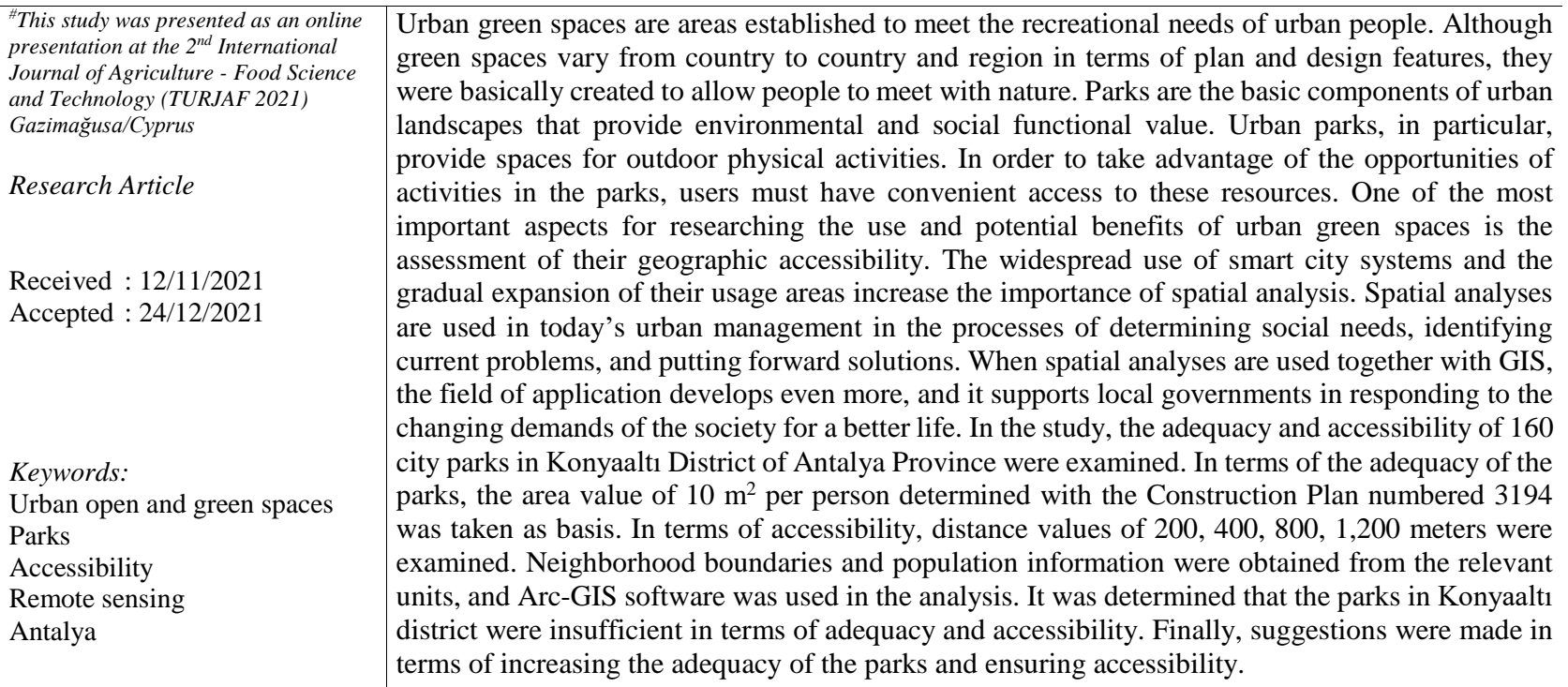 \\ Keywords: \\ Pan open and green spaces \\ Accessibility \\ Remote sensing \\ terms of increasing the adequacy of the parks and ensuring accessibility.
}

\section{Introduction}

The city is an open system that is not static physically and socio-economically, but is dynamic or is called a temporary system (Irwan, 2005). Cities are established as the administrative center of a region and empirically aim to create a place where various communities engage in social activities of different sizes. A sustainable urban city is characterized by a balanced interaction and interrelationship between nature and human in the midst of coexistence (Rahmy et al., 2012). One of the most important conditions in urban planning is the existence of open and green spaces, which has become a necessity due to their abundant functions. The open space accommodates the individual or social activities of the people around it. Its shape largely depends on the model and structure of the building mass (Hakim, 1987). Parks are important in terms of providing a window to social life in urban areas as well as rural development (Leng and Li, 2016). The open space is equipped with roads, parking lots, walkways and trash cans to meet the needs of the community (Kristianova, 2016; Nastiti and Giyarsih, 2019). Green spaces in metropolitan areas, such as urban parks, provide various ecological, economic and social benefits to the city, and are considered a critical component of the quality of life of city residents. In addition, urban parks provide opportunities for different types of leisure activities and play an important role in promoting physical activities and social interactions among different communities, for this reason reducing the stress of users and improving their physical and mental health (Feng et al., 2016). Many studies have investigated the landscape patterns (Belen and Şahin, 2021; Tuffery et al., 2021), ecological effects (Kurjakov et al., 2017; Yavuz and Vatandaşlar, 2018) and accessibility (Beyli and Yeşil, 2020; Aslan and Ankaya, 2020; Li et al., 2021; Zhang et al., 2021)) of urban parks. 
In this study, the adequacy of the parks of Antalya Province, Konyaaltı district was investigated. Konyaaltı district has been chosen as the study area because it has a great tourism potential, is within the borders of the Konyaaltı coastline, and is the area with the highest number of tourists among the central districts of Antalya. There are 157 parks (in the data obtained from the relevant units, this number is 161 and the park with the same name is presented in 4 parts) in Konyaaltı district. Within the scope of the study, the accessibility and adequacy of these parks were investigated. When the studies carried out to date are examined, although there have been many studies on the accessibility and adequacy of the parks, the limited number of studies on this subject for the province of Antalya reveals the importance of the study. In the studies, it was determined that the adequacy of the parks in terms of disabled individuals was generally investigated (Öter, 2018). With this study, it was tried to determine the accessibility of the parks in terms of neighborhoods in the district. It is thought that this study will be an example for future studies in the region. In addition to these benefits, the study also has some limiting factors. For example, in some neighborhood districts of Konyaalt1, a large part of the areal distribution is located in mountainous or forested areas. Therefore, the ratio of accessible areas to parks in these neighborhoods has been lower than in other neighborhoods. However, this error was tried to be minimized by including the green spaces outside the park in these neighborhoods (pancake house, ski resort, camping areas, etc.) into the scope of the study. In addition, it has been determined that the open and green spaces in these neighborhoods are within the settlement and although this is the way, there are problems in terms of accessibility in some areas.

\section{Materials and Method}

Within the scope of the study, the parks of Antalya Province Konyaaltı District were examined (Figure 1). Konyaaltı district is located between $30^{\circ} 42^{\prime} 14.5584^{\prime}$ ' east longitude and $36^{\circ} 53^{\prime} 5.2944^{\prime \prime}$ north latitude.

Within the scope of the study, first of all, information about the population of Konyaaltı district and its parks was obtained from the relevant units of Konyaalt 1 Municipality. The purpose of obtaining this information is to determine the spatial distribution of the parks and the amount of green space per person in the neighborhood. The "Construction Law" numbered 3194 was taken as a reference in determining the amount of green space per capita. According to the relevant law, the amount of green space per person is determined as $10 \mathrm{~m}^{2}$.

The spatial adequacy of the parks has been decided by taking this value as a reference. When the previous studies were examined (Gündoğdu, 2019; Beyli and Yeşil, 2020), it was determined that analyzes were made according to the distance values of 400, 800, 1200 meters in terms of accessibility of the parks.

Within the scope of the study, it was determined that there are too many settlements within 200 meters of parks and some neighborhoods in Konyaaltı district, and besides these values, the distance value of 200 meters was also examined within the scope of the study.

Neighborhood boundaries, population information and location information of parks were digitized using Arc-GIS
10.8 software. After the transfer of these data, the "Multiple Ring Buffer" command in the Arc-GIS 10.8 software was used to identify the 200, 400, 800 and 1200 meters distances determined.

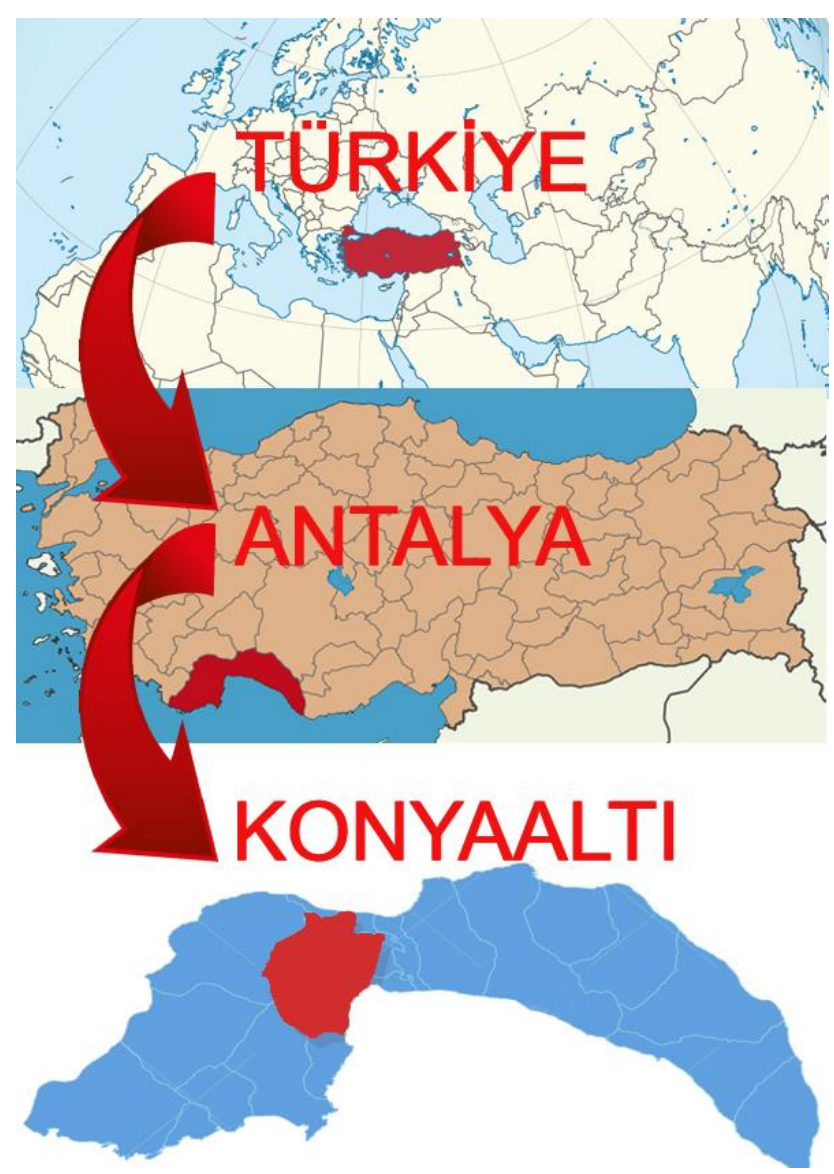

Figure 1. Location of the study area

The spatial distribution of the neighborhoods according to their distance from the parks on the obtained map was calculated using Microsoft Office Excel 2013 software. With this process, the amount of green space per capita $\left(\mathrm{m}^{2}\right)$ in Konyaaltı district on a neighborhood basis and the amount of green space per capita $\left(\mathrm{m}^{2}\right)$ considering the whole of Konyaaltı district was calculated.

Finally, in line with the data obtained, the adequacy and accessibility of the parks of Konyaaltı district were identified and suggestions were developed.

\section{Results and Discussion}

According to the results of the analysis, there are 157 parks in Konyaaltı district. The locations of the parks are given in Figure 1, and the information about the parks is given in Table 1. Located in Konyaaltı district, Gürsu is the neighborhood with the most parks with 20, Liman 18 , Uncal1 12. There are no parks in 14 neighborhoods in the district (Akdamlar, Aşağıkaraman, Bahtılı, Çamlıbel, Çitdibi, Dağ, Demircilik, Gökdere, Hacısekililer, Hisarçandır, Kuruçay, Suiçecek, Üçoluk, Yeni).

The 200, 400, 800 and 1.200 meters distances of the neighborhoods within the district, determined in terms of accessibility to the parks, are given in Figure 3 and their spatial distributions are given in Table 2. 
Table 1. Properties of the Konyaaltı District's parks

\begin{tabular}{l|lllr}
\hline No & \multicolumn{1}{c}{ Park } & Neighborhood & \multicolumn{1}{c}{ Address } & \multicolumn{1}{c}{ Area $\left(\mathrm{m}^{2}\right)$} \\
\hline 1 & Zübeyde Hanim Park & Altinkum & 430 St./437 St. Intersection & 2.020 \\
2 & Park & Altinkum & 416 St./419 St. Intersection & 1.230 \\
3 & Park & Altinkum & 419 St. / Belediye Road. Intersection & 438 \\
159 & Park & Yarbaşçandir & Inside the school garden & 500 \\
160 & Park & Saklikent & Mokamp Area & 17.860 \\
161 & Park & Liman & Above the Akdeniz Boulevard & 1.550 \\
\hline \multicolumn{7}{r}{} & & & Total & 693.481 \\
\hline
\end{tabular}

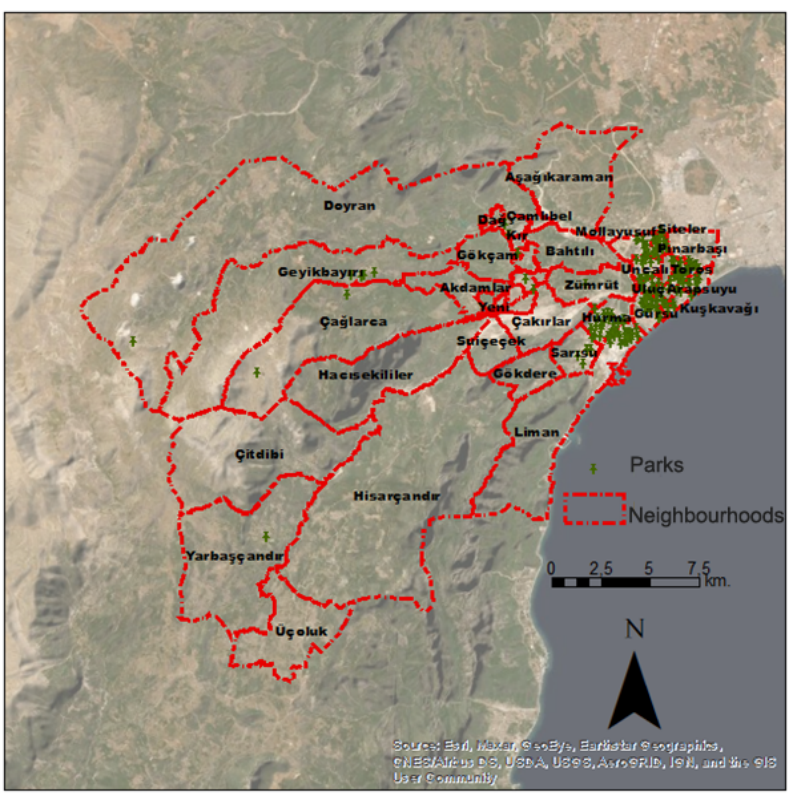

Figure 2. Parks of Konyaaltı District

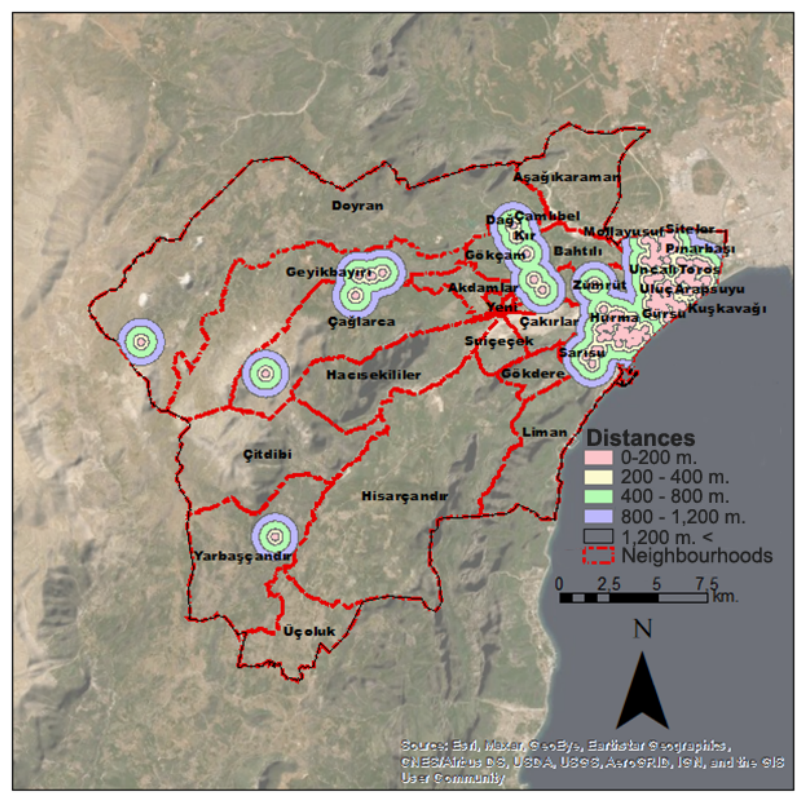

Figure 3. The distances of Konyaaltı neighborhoods to the parks

Table 2. Spatial distribution of the distances to the parks of Konyaaltı neighborhoods

\begin{tabular}{|c|c|c|c|c|}
\hline Neighborhood Name & Distance (m) & & Area $\left(m^{2}\right)$ & Percent (\%) \\
\hline \multirow{6}{*}{ Akdamlar } & $0-200$ & & 0.00 & 0.00 \\
\hline & $200-400$ & & 0.00 & 0.00 \\
\hline & $400-800$ & & 6.913 .03 & 0.11 \\
\hline & $800-1.200$ & & 165.743 .62 & 2.72 \\
\hline & $1,200<$ & & 5.923 .653 .79 & 97.17 \\
\hline & & Total & 6.096 .310 .45 & 100.00 \\
\hline \multirow{6}{*}{ Akkuyu } & $0-200$ & & 195.423 .32 & 22.58 \\
\hline & $200-400$ & & 497.643 .15 & 57.50 \\
\hline & $400-800$ & & 172.423 .91 & 19.92 \\
\hline & $800-1.200$ & & 0.00 & 0.00 \\
\hline & $1,200<$ & & 6.09 & 0.00 \\
\hline & & Total & 865.496 .47 & 100.00 \\
\hline \multirow{6}{*}{ Altınkum } & $0-200$ & & 637.862 .77 & 86.74 \\
\hline & $200-400$ & & 97.552 .51 & 13.26 \\
\hline & $400-800$ & & 0.00 & 0.00 \\
\hline & $800-1.200$ & & 0.00 & 0.00 \\
\hline & $1,200<$ & & 0.00 & 0.00 \\
\hline & & Total & 735.415 .28 & 100.00 \\
\hline \multirow{6}{*}{ Arapsuyu } & $0-200$ & & 648.009 .43 & 48.42 \\
\hline & $200-400$ & & 508.122 .75 & 37.97 \\
\hline & $400-800$ & & 182.214 .03 & 13.61 \\
\hline & $800-1.200$ & & 0.00 & 0.00 \\
\hline & $1,200<$ & & 0.00 & 0.00 \\
\hline & & Total & 1.338 .346 .21 & 100.00 \\
\hline \multirow{6}{*}{ Aşağıkaraman } & $0-200$ & & 0.00 & 0.00 \\
\hline & $200-400$ & & 0.00 & 0.00 \\
\hline & $400-800$ & & 0.00 & 0.00 \\
\hline & $800-1.200$ & & 0.00 & 0.00 \\
\hline & $1,200<$ & & 21.196.512.77 & 100.00 \\
\hline & & Total & 21.196 .512 .77 & 100.00 \\
\hline
\end{tabular}


Table 2. Spatial distribution of the distances to the parks of Konyaaltı neighborhoods

\begin{tabular}{|c|c|c|c|}
\hline Neighborhood Name & Distance $(\mathrm{m})$ & Area $\left(\mathrm{m}^{2}\right)$ & Percent $(\%)$ \\
\hline \multirow{6}{*}{ Aydınlık } & $0-200$ & 173.794 .80 & 26.46 \\
\hline & $200-400$ & 480.647 .03 & 73.19 \\
\hline & $400-800$ & 1.600 .00 & 0.24 \\
\hline & $800-1.200$ & 672.99 & 0.10 \\
\hline & $1,200<$ & 5.35 & 0.00 \\
\hline & Total & 656.720 .17 & 100.00 \\
\hline \multirow{6}{*}{ Baht1lı } & $0-200$ & 0.00 & 0.00 \\
\hline & $200-400$ & 0.00 & 0.00 \\
\hline & $400-800$ & 148.408 .93 & 1.87 \\
\hline & $800-1.200$ & 1.581 .564 .64 & 19.91 \\
\hline & $1,200<$ & 6.212 .299 .43 & 78.22 \\
\hline & Total & 7.942 .272 .99 & 100.00 \\
\hline \multirow{6}{*}{ Çağlarca } & $0-200$ & 251.162 .08 & 0.67 \\
\hline & $200-400$ & 754.520 .49 & 2.00 \\
\hline & $400-800$ & 3.247 .829 .52 & 8.60 \\
\hline & $800-1.200$ & 4.544 .758 .35 & 12.03 \\
\hline & $1,200<$ & 28.966 .105 .32 & 76.70 \\
\hline & Total & 37.764 .375 .76 & 100.00 \\
\hline \multirow{6}{*}{ Çakırlar } & $0-200$ & 91.472 .04 & 1.06 \\
\hline & $200-400$ & 218.473 .31 & 2.53 \\
\hline & $400-800$ & 963.301 .08 & 11.14 \\
\hline & $800-1.200$ & 1.247 .371 .65 & 14.43 \\
\hline & $1,200<$ & 6.122 .866 .90 & 70.84 \\
\hline & Total & 8.643 .484 .98 & 100.00 \\
\hline \multirow{5}{*}{ Çamlıbel } & $0-200$ & 183.683 .17 & 13.69 \\
\hline & $200-400$ & 398.747 .98 & 29.71 \\
\hline & $400-800$ & 485.993 .54 & 36.22 \\
\hline & $800-1.200$ & 247.921 .49 & 18.47 \\
\hline & $1,200<$ & 25.599 .25 & 1.91 \\
\hline \multirow{5}{*}{ Çitdibi } & $0-200$ & 0.00 & 0.00 \\
\hline & $200-400$ & 0.00 & 0.00 \\
\hline & $400-800$ & 0.00 & 0.00 \\
\hline & $800-1.200$ & 0.00 & 0.00 \\
\hline & $1,200<$ & 36.877 .724 .01 & 100.00 \\
\hline \multirow{6}{*}{ Dağ } & $0-200$ & 0.00 & 0.00 \\
\hline & $200-400$ & 7.296 .52 & 1.02 \\
\hline & $400-800$ & 327.784 .69 & 46.01 \\
\hline & $800-1.200$ & 374.996 .82 & 52.64 \\
\hline & $1,200<$ & 2.317 .72 & 0.33 \\
\hline & Total & 712.395 .75 & 100.00 \\
\hline \multirow{6}{*}{ Demircilik } & $0-200$ & 0.00 & 0.00 \\
\hline & $200-400$ & 2.284 .03 & 0.31 \\
\hline & $400-800$ & 264.993 .64 & 35.72 \\
\hline & $800-1.200$ & 286.653 .39 & 38.64 \\
\hline & $1,200<$ & 187.862 .71 & 25.33 \\
\hline & Total & 741.793 .78 & 100.00 \\
\hline \multirow{6}{*}{ Doyran } & $0-200$ & 125.581 .05 & 0.13 \\
\hline & $200-400$ & 385.417 .19 & 0.40 \\
\hline & $400-800$ & 1.732 .140 .57 & 1.78 \\
\hline & $800-1.200$ & 3.237 .691 .99 & 3.32 \\
\hline & $1,200<$ & 92.039 .810 .66 & 94.38 \\
\hline & Total & 97.520 .641 .45 & 100.00 \\
\hline \multirow{6}{*}{ Geyikbayırı } & $0-200$ & 435.505 .75 & 1.05 \\
\hline & $200-400$ & 970.044 .75 & 2.35 \\
\hline & $400-800$ & 1.775 .746 .89 & 4.30 \\
\hline & $800-1.200$ & 2.202 .144 .03 & 5.33 \\
\hline & $1,200<$ & 35.929 .594 .81 & 86.97 \\
\hline & Total & 41.313 .036 .22 & 100.00 \\
\hline
\end{tabular}


Table 2. Spatial distribution of the distances to the parks of Konyaaltı neighborhoods

\begin{tabular}{|c|c|c|c|}
\hline Neighborhood Name & Distance $(\mathrm{m})$ & Area $\left(\mathrm{m}^{2}\right)$ & Percent $(\%)$ \\
\hline \multirow{6}{*}{ Gökçam } & $0-200$ & 27.230 .68 & 0.46 \\
\hline & $200-400$ & 213.892 .10 & 3.61 \\
\hline & $400-800$ & 1.037.094.21 & 17.51 \\
\hline & $800-1.200$ & 1.208.964.32 & 20.42 \\
\hline & $1,200<$ & 3.434 .520 .14 & 58.00 \\
\hline & Total & 5.921 .701 .44 & 100.00 \\
\hline \multirow{6}{*}{ Gökdere } & $0-200$ & 0.00 & 0.00 \\
\hline & $200-400$ & 0.00 & 0.00 \\
\hline & $400-800$ & 0.00 & 0.00 \\
\hline & $800-1.200$ & 89.774 .76 & 1.62 \\
\hline & $1,200<$ & 5.456 .501 .12 & 98.38 \\
\hline & Total & 5.546 .275 .88 & 100.00 \\
\hline \multirow{6}{*}{ Gürsu } & $0-200$ & 1.068 .493 .64 & 45.55 \\
\hline & $200-400$ & 723.959 .98 & 30.86 \\
\hline & $400-800$ & 553.447 .72 & 23.59 \\
\hline & $800-1.200$ & 0.00 & 0.00 \\
\hline & $1,200<$ & 0.00 & 0.00 \\
\hline & Total & 2.345 .901 .33 & 100.00 \\
\hline \multirow{6}{*}{ Hacısekililer } & $0-200$ & 0.00 & 0.00 \\
\hline & $200-400$ & 0.00 & 0.00 \\
\hline & $400-800$ & 0.00 & 0.00 \\
\hline & $800-1.200$ & 0.00 & 0.00 \\
\hline & $1,200<$ & 25.992 .361 .50 & 100.00 \\
\hline & Total & 25.992.361.50 & 100.00 \\
\hline \multirow{6}{*}{ Hisarçandır } & $0-200$ & 0.00 & 0.00 \\
\hline & $200-400$ & 0.00 & 0.00 \\
\hline & $400-800$ & 0.00 & 0.00 \\
\hline & $800-1.200$ & 840.33 & 0.00 \\
\hline & $1,200<$ & 81.736 .361 .67 & 100.00 \\
\hline & Total & 81.737.202.00 & 100.00 \\
\hline \multirow{6}{*}{ Hurma } & $0-200$ & 1.696 .479 .55 & 46.67 \\
\hline & $200-400$ & 925.532 .17 & 25.46 \\
\hline & $400-800$ & 849.255 .94 & 23.36 \\
\hline & $800-1.200$ & 163.861 .87 & 4.51 \\
\hline & $1,200<$ & 0.13 & 0.00 \\
\hline & Total & 3.635 .129 .66 & 100.00 \\
\hline \multirow{6}{*}{ Karatepe } & $0-200$ & 56.126 .34 & 4.47 \\
\hline & $200-400$ & 191.564 .30 & 15.26 \\
\hline & $400-800$ & 820.188 .63 & 65.35 \\
\hline & $800-1.200$ & 187.246.11 & 14.92 \\
\hline & $1,200<$ & 0.00 & 0.00 \\
\hline & Total & 1.255 .125 .38 & 100.00 \\
\hline \multirow{6}{*}{ Kir } & $0-200$ & 109.702 .96 & 15.20 \\
\hline & $200-400$ & 216.773 .64 & 30.03 \\
\hline & $400-800$ & 384.347 .47 & 53.24 \\
\hline & $800-1.200$ & 11.093 .29 & 1.54 \\
\hline & $1,200<$ & 0.00 & 0.00 \\
\hline & Total & 721.917 .38 & 100.00 \\
\hline \multirow{6}{*}{ Kuruçay } & $0-200$ & 0.00 & 0.00 \\
\hline & $200-400$ & 28.436 .93 & 5.91 \\
\hline & $400-800$ & 279.149 .82 & 58.03 \\
\hline & $800-1.200$ & 152.965 .96 & 31.80 \\
\hline & $1,200<$ & 20.467 .10 & 4.25 \\
\hline & Total & 481.019 .81 & 100.00 \\
\hline \multirow{6}{*}{ Kuşkavağ1 } & $0-200$ & 405.728 .94 & 50.29 \\
\hline & $200-400$ & 350.392 .44 & 43.43 \\
\hline & $400-800$ & 50.617 .88 & 6.27 \\
\hline & $800-1.200$ & 0.00 & 0.00 \\
\hline & $1,200<$ & 0.73 & 0.00 \\
\hline & Total & 806.739 .98 & 100.00 \\
\hline
\end{tabular}


Table 2. Spatial distribution of the distances to the parks of Konyaaltı neighborhoods

\begin{tabular}{|c|c|c|c|}
\hline Neighborhood Name & Distance $(\mathrm{m})$ & Area $\left(\mathrm{m}^{2}\right)$ & Percent $(\%)$ \\
\hline \multirow{6}{*}{ Liman } & $0-200$ & 1.381 .310 .45 & 5.12 \\
\hline & $200-400$ & 786.556 .56 & 2.91 \\
\hline & $400-800$ & 1.278 .395 .36 & 4.74 \\
\hline & $800-1.200$ & 1.309 .971 .41 & 4.85 \\
\hline & $1,200<$ & 22.228 .709 .76 & 82.37 \\
\hline & Total & 26.984 .943 .54 & 100.00 \\
\hline \multirow{6}{*}{ Mollayusuf } & $0-200$ & 561.079 .07 & 25.93 \\
\hline & $200-400$ & 596.153 .52 & 27.55 \\
\hline & $400-800$ & 597.760 .06 & 27.63 \\
\hline & $800-1.200$ & 353.672 .69 & 16.34 \\
\hline & $1,200<$ & 55.141 .36 & 2.55 \\
\hline & Total & 2.163 .806 .70 & 100.00 \\
\hline \multirow{6}{*}{ Öğretmenevleri } & $0-200$ & 574.865 .57 & 68.96 \\
\hline & $200-400$ & 258.508 .77 & 31.01 \\
\hline & $400-800$ & 303.26 & 0.04 \\
\hline & $800-1.200$ & 0.00 & 0.00 \\
\hline & $1,200<$ & 1.33 & 0.00 \\
\hline & Total & 833.678 .93 & 100.00 \\
\hline \multirow{6}{*}{ Pınarbaşı } & $0-200$ & 567.399 .96 & 13.24 \\
\hline & $200-400$ & 687.840 .55 & 16.05 \\
\hline & $400-800$ & 1.237 .298 .45 & 28.87 \\
\hline & $800-1.200$ & 932.083 .53 & 21.75 \\
\hline & $1,200<$ & 861.150 .42 & 20.09 \\
\hline & Total & 4.285 .772 .91 & 100.00 \\
\hline \multirow{6}{*}{ Sarısu } & $0-200$ & 578.617 .96 & 13.71 \\
\hline & $200-400$ & 1.095 .649 .16 & 25.96 \\
\hline & $400-800$ & 1.347 .255 .31 & 31.93 \\
\hline & $800-1.200$ & 1.011 .597 .19 & 23.97 \\
\hline & $1,200<$ & 186.897 .26 & 4.43 \\
\hline & Total & 4.220 .016 .88 & 100.00 \\
\hline \multirow{6}{*}{ Siteler } & $0-200$ & 912.446 .41 & 89.99 \\
\hline & $200-400$ & 101.530 .11 & 10.01 \\
\hline & $400-800$ & 0.00 & 0.00 \\
\hline & $800-1.200$ & 0.00 & 0.00 \\
\hline & $1,200<$ & 0.00 & 0.00 \\
\hline & Total & 1.013 .976 .52 & 100.00 \\
\hline \multirow{6}{*}{$\mathrm{Su}$ içecek } & $0-200$ & 5.785 .88 & 0.10 \\
\hline & $200-400$ & 73.973 .90 & 1.25 \\
\hline & $400-800$ & 249.505 .74 & 4.23 \\
\hline & $800-1.200$ & 347.934 .04 & 5.90 \\
\hline & $1,200<$ & 5.224 .200 .30 & 88.52 \\
\hline & Total & 5.901 .399 .86 & 100.00 \\
\hline \multirow{6}{*}{ Toros } & $0-200$ & 594.318 .24 & 86.58 \\
\hline & $200-400$ & 92.142 .84 & 13.42 \\
\hline & $400-800$ & 0.00 & 0.00 \\
\hline & $800-1.200$ & 0.00 & 0.00 \\
\hline & $1,200<$ & 0.16 & 0.00 \\
\hline & Total & 686.461 .25 & 100.00 \\
\hline \multirow{6}{*}{ Uluç } & $0-200$ & 508.662 .81 & 67.15 \\
\hline & $200-400$ & 247.400 .21 & 32.66 \\
\hline & $400-800$ & 1.483 .09 & 0.20 \\
\hline & $800-1.200$ & 0.00 & 0.00 \\
\hline & $1,200<$ & 0.00 & 0.00 \\
\hline & Total & 757.546 .12 & 100.00 \\
\hline \multirow{6}{*}{ Üçoluk } & $0-200$ & 0.00 & 0.00 \\
\hline & $200-400$ & 0.00 & 0.00 \\
\hline & $400-800$ & 0.00 & 0.00 \\
\hline & $800-1.200$ & 0.00 & 0.00 \\
\hline & $1,200<$ & 15.933 .449 .24 & 100.00 \\
\hline & Total & 15.933 .449 .24 & 100.00 \\
\hline
\end{tabular}


Table 2. Spatial distribution of the distances to the parks of Konyaaltı neighborhoods

\begin{tabular}{l|ccc}
\hline Neighborhood Name & Distance $(\mathrm{m})$ & Area $\left(\mathrm{m}^{2}\right)$ & Percent $(\%)$ \\
\hline \multirow{4}{*}{ Yarbaşçandır } & $0-200$ & 125.581 .06 & 0.36 \\
& $200-400$ & 376.907 .44 & 1.09 \\
& $400-800$ & 1.507 .796 .69 & 4.37 \\
& $800-1.200$ & 2.512 .267 .97 & 7.29 \\
& $1,200<$ & 29.956 .794 .36 & 86.88 \\
Yeni & Total & 34.479 .347 .52 & 100.00 \\
& $0-200$ & 0.00 & 0.00 \\
& $200-400$ & 0.00 & 0.00 \\
& $400-800$ & 0.00 & 0.00 \\
& $800-1.200$ & 6.316 .30 & 1.34 \\
Zümrüt & $1,200<$ & 464.813 .13 & 98.66 \\
& Total & 471.129 .43 & 100.00 \\
\hline & $0-200$ & 149.890 .05 & 2.12 \\
& $200-400$ & 545.213 .25 & 7.70 \\
& $400-800$ & 2.471 .804 .72 & 34.92 \\
& $800-1.200$ & 2.531 .436 .03 & 35.77 \\
& $1,200<$ & 1.379 .172 .91 & 19.49 \\
\hline
\end{tabular}

According to the results of the analysis, $2.58 \%$ of the districts of Konyaaltı are $0-200$ meters to the parks, $2.51 \% 200-400$ meters, $4.50 \% 400-800$ meters, $4.95 \%$ $800-1.200$ meters, and $85.45 \%$ are more farther than 1,200 meters. Considering the neighborhoods within the borders of Konyaaltı district and the entire population of the district, the amount of green space per capita is given in Figure 4 and Table 3.

In Konyaalt1 district, the amount of green space per person per capita in 16 neighborhoods in total is $0.00 \mathrm{~m}^{2}$, in 2 neighborhoods $0.01-1.00 \mathrm{~m}^{2}$, in 8 neighborhoods 1.01 - $3.00 \mathrm{~m}^{2}$, in 5 neighborhoods $3.01-5.00 \mathrm{~m}^{2}, 4$ It was determined that it is larger than $5.01-10.00 \mathrm{~m}^{2}$ in the neighborhood and $10.01 \mathrm{~m}^{2}$ in 4 neighborhoods. It has been determined that the number of parks in Konyaaltı district is not equally distributed on the basis of neighborhoods. The number of parks in Altınkum, Siteler, Gürsu, Liman, Hurma and Uncalı neighborhoods is much higher than in other neighborhoods. In addition, 16 of 39 neighborhoods in the district do not have a park. Although the number of parks in Konyaaltı district seems to be sufficient, it is not sufficient to meet the needs of the population living in the district. According to the Construction Law Numbered 3194 , the amount of green space per person must be at least $10 \mathrm{~m}^{2}$. Only 4 neighborhoods out of 39 neighborhoods in Konyaalt 1 have reached this value. Considering the area and population of all parks within the boundaries of the district, the amount of green space per capita is $3.67 \mathrm{~m}^{2}$. The fact that the number of parks in the district is low or the areas of the existing parks are not large enough to meet the needs of the users show that the parks of Konyaalt1 District are not sufficient quantitatively. Neighborhood parks are green spaces within the urban fabric that serve dense residential groups 400-800 $\mathrm{m}$ from the residences (Yıldızcı, 1982; Beyli and Yeşil, 2020).

In terms of accessibility to parks in Konyaaltı, only 11 neighborhoods comply with these values. These neighborhoods are; Akkuyu, Altınkum, Arapsuyu, Aydınlık, Gürsu, Hurma, Kuşkavağı, Öğretmenevleri, Siteler, Toros and Uluç. It has been determined that these 11 neighborhoods are located in the district center and are close to tourism facilities, Konyaaltı beach and Akdeniz University campus. For this reason, it has been determined that the number of parks within the district does not have an equal distribution on the basis of neighborhoods, and there are problems in terms of accessibility to park areas in neighborhoods far from the district center. When the studies on the subject (Aykal et al., 2017; Şenkaya et al., 2019; Beyli and Yeşil, 2020) are examined, there are similar results; they have determined, considering the population of the neighborhoods and the adequacy of the parking areas, it was determined that very few neighborhoods were above the standards, while the other neighborhoods were below the standards.

\section{Conclusions}

Parks are one of the most important components of urban open and green spaces. People have fun, rest, read a book, etc. Parks are at the forefront of the active green areas they use for their activities.

Therefore, the location and size of the parks should be well planned. In order to create an accessible and spatially sufficient green space, the locations and population information of the residential areas should be analyzed in detail. Instead of building many small parks in densely populated areas, a small number of parks that are large in area should be designed.

The size of these parks should be planned to meet the needs of the people living in the region and to be at least $10 \mathrm{~m}^{2}$ per person. A small number of large parks should be designed in areas where the population is low and construction is concentrated in certain areas, and a large number of small parks should be designed in areas where it is scattered.

In many neighborhoods located in the center of Konyaaltı, the construction is concentrated in certain areas. However, settlements in neighborhoods such as Çakırlar, Hisarçandır, Yarbaşçandır and Aşağıkaraman are scattered. In these areas, parks should be designed in accordance with the location of the settlements. 
In the current situation, the number of parks in these areas is almost non-existent. The amount of green space per capita in Öğretmenevleri, Uluç, Doyran and Zümrüt districts is over $10 \mathrm{~m}^{2}$. The amount of green space should be increased in 35 neighborhoods other than these neighborhoods. However, not only the spatial size of the new parks, but also their accessibility should be considered.Of the 4 neighborhoods where the amount of green space per capita is sufficient, only Öğretmenevleri and Uluç neighborhoods are found to be suitable in terms of accessibility. Although the parks in Doyran and Zümrüt neighborhoods are sufficient in terms of area, they are not accessible. The location of the parks that are planned to be built in these neighborhoods is the first issue to be considered. The parks to be built in Doyran and Zümrüt areas should be close to the structures. In other neighborhoods within the district, there are serious problems in terms of both quantity and accessibility. The parks to be built in these neighborhoods should be large enough to increase the amount of green space per capita to $10 \mathrm{~m}^{2}$. In its current state, the amount of active green space in Konyaaltı is $639,481.00 \mathrm{~m}^{2}$. In order to achieve the amount of green space per capita determined according to the Construction Law numbered 3194, 1.197,299.00 $\mathrm{m}^{2}$ more green areas are needed. In addition, a plan should be made in such a way that the distance of these new parks to the settlement areas will be maximum 800 meters.

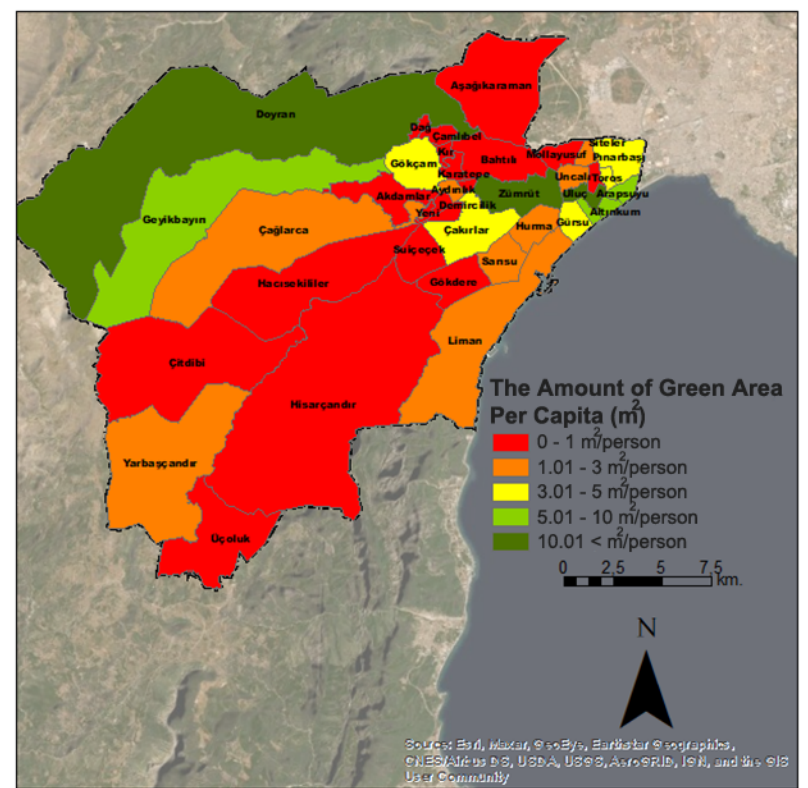

Figure 4. The amount of green space per capita at the neighborhoods

Table 3. The amount of green space per capita in Konyaalt

\begin{tabular}{l|lc|c}
\hline \multicolumn{1}{c|}{ No } & \multicolumn{1}{|c|}{ Neihborhoods } & P & GSPC \\
\hline 1 & Akdamlar Neihborhood & 419 & 0.00 \\
2 & Akkuyu Neihborhood & 3.477 & 0.00 \\
3 & Altınkum Neihborhood & 8.503 & 8.44 \\
158 & Uncalı Neihborhood & 18.013 & 1.82 \\
159 & Yarbaşçandır Neihborhood & 410 & 1.22 \\
160 & Yeni Neihborhood & 358 & 0.00 \\
161 & Zümrüt Neihborhood & 262 & 32.44 \\
\hline \multicolumn{3}{c}{ Amount of Green Spaces Per Capita in } & 3.67 \\
\hline \multicolumn{3}{c}{ Konyaaltı District $\left(\mathrm{m}^{2}\right)$} \\
\hline
\end{tabular}

P: Population, GSPC: Green space per capita $\left(\mathrm{m}^{2}\right)$
As a result; During the planning and design stages of parks, the historical development and cultural characteristics of the neighborhoods should be taken into account. The natural features of the area, land form, population density should be determined, and the size and form of the parks should be shaped according to these features.

The parks, which have a size that will appeal to all the people of the neighborhood, should be distributed homogeneously within the neighborhood and should be accessible at the same time. The age group distributions and socio-cultural characteristics of the neighborhood populations should be investigated and the equipment elements that make the parks functional, green areas and children's playgrounds should be shaped according to needs (Beyli and Yeşil, 2020).

\section{References}

Aykal FD, Yilmaz A, Çelik S. 2017. A Study on the Accessibility of Urban Parks: The Case of Van Dilek Doğan City Park. Journal of Engineering Sciences and Design, 5, 29-40.

Aslan BG, Ankaya FÜ. 2020. Evaluation of Turkey (İzmir/Bornova) Büyük Park in terms of Disabled Standards in the Scope of Urban Landscape. National Environmental Science Research Journal, 3(3), 110-118.

Belen N, Sahin S. 2021. Historical Landscape Character Areas as Memory Bearers: The Case of the Ancient City of Priene. GSI Journals Serie C: Advancements in Information Sciences and Technologies, 4(2), 38-57.

Beyli KN, Yeşil M. 2020. A Study on Adequacy and Accessibility of Ordu City Parks. Gumushane University Journal of Science Institute, 10 (2), 492-504.

Feng S, Chen L, Sun R, Feng Z, Li J, Khan MS, Jing Y. 2019. The distribution and accessibility of urban parks in Beijing, China: Implications of social equity. International journal of environmental research and public health, 16(24), 4894.

Gündoğdu H. 2019. Examination of parks in terms of accessibility in the examples of Ankara Dikmen Valley Park, Göksu Park and Can Yücel Park. (Unpublished Master Thesis). Ankara University Institute of Science, Ankara, $166 \mathrm{p}$.

Hakim C. 1987. Research design. Strategies and choices in the design of social research. Boston: Unwin Hyman. ISBN: 9780043120323.

Irwan ZD. 2005. Challenge in Environmental and Urban Forest Landscape. pp:10-30. Jakarta: Bumi Aksara Press.

Kristianova K. 2016. Post-socialist transformations of green open spaces in large scale socialist housing estates in Slovakia. Procedia engineering, 161, 1863-1867.

Kurjakov A, Čukanović J, Blagojević M, Mladenović E, Hiel K, Vukićević S. 2017. Ecological Analysis of the Dendroflora of Futoški Park in the City of Novi Sad. Contemporary Agriculture, 66(1-2), 7-13.

Leng H, Li T. 2016. Research on Public Open Space of Rural Areas in Severe Cold Regions Based on Survey of Residents on the Behavioral Activity. Procedia Engineering, 146, 327334.

Li Z, Fan Z, Song Y, Chai Y. 2021. Assessing equity in park accessibility using a travel behavior-based G2SFCA method in Nanjing, China. Journal of Transport Geography, 96, 103179.

Nastiti FN, Giyarsih SR. 2019. Green Open Space in Urban Areas: A Case in the Government Office of Boyolali, Indonesia. Regional Science Inquiry, 11(1), 19-28.

Öter B. 2018. A research on the application of space syntax method in accessibility studies in Antalya city center. Master Thesis, Akdeniz Uni. Institute of Science and Technology, Department of Landscape Architecture, Antalya, 118 p. 
Rahmy WA, Faisal B, Soeriaatmadja AR. 2012. Kebutuhan ruang terbuka hijau kota pada kawasan padat, studi kasus di wilayah Tegallega, Bandung. Jurnal Lingkungan Binaan Indonesia, $1(1), 27-38$.

Şenkaya Ü, Özdemir Y, Özdemir Ş. 2019. A research on the accessibility of parks: The case of Findikzade Çukurbostan Life Park. Istanbul Sabahattin Zaim University Journal of Science Institute, 1(2), 53-57.

Tufféry L, Davi H, López-García N, Rigolot E, Jean F, Stenger A, Lefevre F. 2021. Adaptive measures for mountain Mediterranean forest ecosystem services under climate and land cover change in the Mont-Ventoux regional nature park, France. Regional Environmental Change, 21(1), 1-14.
Yavuz M, Vatandaşlar C. 2018. Monitoring the temporal and ecological changes of protected areas with the help of fragmentation analysis: The case of Karagöl-Sahara National Park. Forestry Research Journal, 5(1), 82-96.

Yildizci AC. 1982. Urban Green Area Planning and the Example of Istanbul. ITU Faculty of Architecture. Unpublished Associate Professor Thesis, Istanbul.

Zhang J, Cheng Y, Zhao B. 2021. How to accurately identify the underserved areas of peri-urban parks? An integrated accessibility indicator. Ecological Indicators, 122, 107263. 